\title{
Pengaruh Kecerdasan Intelektual, Kecerdasan Emosional, Kecerdasan Spiritual, dan Perilaku Belajar Terhadap Pemahaman Akuntansi
}

\author{
Ni Putu Laksmi Gayatri ${ }^{1}$ \\ Ni Gst. Putu Wirawati ${ }^{2}$ \\ ${ }^{1,2}$ Fakultas Ekonomi dan Bisnis Universitas Udayana (Unud), Bali, Indonesia \\ e-mail: laksmigayatri84@yahoo.com
}

\begin{abstract}
ABSTRAK
Penelitian ini dilakukan pada mahasiswa reguler siang jurusan akuntansi Fakultas Ekonomi dan Bisnis Universitas Udayana. Penelitian ini menggunakan data primer yang dikumpulkan dengan menggunakan kuesioner sebagai instrument pengumpulan data yang disebarkan kepada responden. Responden penelitian ini adalah mahasiswa reguler siang jurusan akuntansi angkatan 2015 Fakultas Ekonomi dan Bisnis Universitas Udayana. Jumlah sampel yang diperoleh sebanyak 65 sampel. Teknik analisis data yang digunakan adalah analisis regresi linier berganda. Hasil analisis menunjukkan bahwa variabel kecerdasan intelektual, kecerdasan emosional, kecerdasan spiritual, dan perilaku belajar berpengaruh positif dan signifikan secara statistik pada pemahaman akuntansi. Hal ini bermakna bahwa semakin baik kecerdasan intelektual, kecerdasan emosional, kecerdasan spiritual, dan perilaku belajar, semakin baik pula pemahaman akuntansi.

Kata kunci: Kecerdasan intelektual, kecerdasan emosional, kecerdasan spiritual, perilaku belajar, pemahaman akuntansi.
\end{abstract}

\begin{abstract}
This research was conducted on regular afternoon students in the accounting department of the Faculty of Economics and Business, Udayana University. This study uses primary data collected using a questionnaire as an instrument for collecting data distributed to respondents. The respondents of this study were regular afternoon students of the 2015 accounting department of the Faculty of Economics and Business, Udayana University. The number of samples obtained was 65 samples. The data analysis technique used is multiple linear regression analysis. The results of the analysis show that the variables of intellectual intelligence, emotional intelligence, spiritual intelligence, and learning behavior have positive and statistically significant effects on the understanding of accounting. This means that the better the intellectual intelligence, emotional intelligence, spiritual intelligence, and learning behavior, the better the understanding of accounting.

Keywords: Intellectual intelligence, emotional intelligence, spiritual intelligence, learning behavior, understanding of accounting.
\end{abstract}

\section{PENDAHULUAN}

Di era globalisasi seperti ini, dunia pendidikan dituntut agar selalu meningkatkan kualitasnya agar manusia Indonesia dapat bertahan dan mampu menyesuaikan diri di era keterbukaan informasi ini. Pendidikan memegang peranan penting dalam menciptakan tingkah laku, mental dan seluruh aspek kehidupan suatu negara 
Ni Putu Laksmi Gayatri dan I Gst. Putu Wirawati. Pengaruh ...

karena pendidikan merupakan salah satu tolak ukur yang menentukan maju atau mundurnya suatu proses pembangunan Negara dalam segala bidang. Dalam sistem pendidikan nasional Indonesia, perguruan tinggi merupakan jenjang pendidikan tertinggi yang diharapkan akan menciptakan manusia berkualitas dan intelektual sehingga mampu mengubah masa depan bangsa menjadi lebih baik.

Hal ini juga sesuai dengan yang dinyatakan oleh Suwardjono (2004) bahwa mahasiswa yang belajar di perguruan tinggi dituntut tidak hanya mempunyai keterampilan teknis tetapi juga memiliki daya dan kerangka pikir serta sikap mental dan kepribadian tertentu, sehingga mempunyai wawasan luas dalam menghadapi masalah-masalah dalam dunia nyata (masyarakat). Daniel (2003) menyatakan bahwa kemampuan akademik bawaan, nilai rapor, dan prediksi kelulusan pendidikan tinggi tidak memprediksi seberapa baik kinerja seseorang sudah bekerja atau seberapa tinggi sukses yang dicapainya dalam hidup. Sebaliknya ia menyatakan bahwa seperangkat kecakapan khusus seperti empati, disiplin diri, dan inisiatif mampu membedakan orang sukses dari mereka yang berprestasi biasa-biasa saja, selain kecerdasan akal yang dapat memengaruhi keberhasilan orang dalam bekerja.

Aktivitas perkuliahan seharusnya dibutuhkan konsentrasi penuh untuk mendapatkan hasil yang memuaskan, dengan konsentrasi penuh kita akan mengerti dan memahami mata kuliah yang diajarkan. Pendidikan tinggi akuntansi ditujukan untuk mendidik mahasiswa agar dapat bekerja sebagai akuntan professional yang tidak sekadar memiliki pengetahuan saja melainkan memiliki pemahaman dalam ilmu akuntansi dengan baik. Oleh karena itu kecerdasan yang 
dimiliki mahasiswa sangat mempengaruhi bagaimana suatu materi yang diberikan dapat dipahami dan disukai.

Menurut Phillips dan Phillips (2007) pendidikan akuntansi yang selama ini diajarkan di perguruan tinggi hanya terkesan sebagai pengetahuan yang berorientasi pada mekanisme secara umum saja, sangat berbeda apabila dibandingkan dengan dengan praktik sesungguhnya yang dihadapi di dunia kerja. Tingkat pendidikan di perguruan tinggi masih menunjukkan hasil yang tidak sesuai dengan yang diharapkan, padahal proses belajar mengajar pada pendidikan tinggi akuntansi hendaknya dapat mentranformasikan peserta didik menjadi lulusan yang lebih utuh sebagai manusia (Mawardi, 2012). Masalah tersebut tentu membingungkan lulusan akuntansi karena pemahaman akuntansi dibangku kuliah ternyata berbeda dengan dunia kerja. Hal ini mendasar pemikiran akan perlunya dalam meningkatkan kecerdasan intelektual, kecerdasan emosional, kecerdasan spiritual, dan perilaku belajar.

Kecerdasan intelektual merupakan hal yang penting untuk dipertimbangkan dalam memahami akuntansi. Dwijayanti (2009) mengatakan bahwa kecerdasan intelektual adalah kemampuan yang dibutuhkan untuk melakukan berbagai aktivitas mental berfikir. Kecerdasan intelektual pada setiap manusia memiliki kapasitas yang berbeda-beda yang kemudian menentukan cara berfikir manusia tersebut. Mahasiswa akuntansi yang memiliki kecerdasan intelektual yang baik tentu memiiki tingkat pemahaman akuntansi yang baik pula.

Salah satu faktor yang dapat mendorong keberhasilan pendidikan tinggi akuntansi selain kecerdasan intelektual itu sendiri adalah mental mahasiswa dalam 
Ni Putu Laksmi Gayatri dan I Gst. Putu Wirawati. Pengaruh ...

mengembangkan kepribadiannya. Mental mahasiswa dalam mengembangkan kepribadiannya sering disebut dengan Kecerdasan Emosional. Daniel (2003) mengungkapkan adanya faktor selain kecerdasan kognitif yang dapat mempengaruhi keberhasilan orang dalam bekerja. Faktor ini dikenal sebagai kecerdasan emosional. Melandy dan Aziza (2006) menyatakan hasil survei yang dilakukan di Amerika Serikat tentang kecerdasan emosional menjelaskan bahwa apa yang diinginkan oleh pemberi kerja tidak hanya keterampilan teknik saja melainkan dibutuhkan kemampuan dasar untuk belajar dalam pekerjaan yang bersangkutan. Diantaranya adalah kemampuan mendengar dan berkomunikasi lisan, adaptasi, kreatifitas, ketahanan mental terhadap kegagalan, kepercayaan diri, motivasi, kerjasama tim, dan keinginan memberi kontribusi terhadap perusahaan.

Peran kecerdasan intelektual dalam dunia kerja ternyata hanya menempati posisi kedua setelah kecerdasan emosional dalam menentukan peraihan prestasi puncak. Kecerdasan emosional merupakan kemampuan merasakan dan memahami secara efektif dalam hal penerapan daya dan kepekaan emosi sebagai sumber energi, informasi, koneksi dan pengaruh yang manusiawi. Kemampuan ini mendukung mahasiswa dalam mencapai tujuan dan cita-citanya. Mahasiswa yang mampu mengendalikan emosinya dapat menghasilkan optimalisasi pada fungsi kecerdasan emosionalnya sehingga dapat memahami akuntansi dengan lebih mudah. Mahasiswa yang memiliki keterampilan emosi yang baik akan berhasil di dalam kehidupan dan memiliki motivasi untuk terus belajar. Namun, mahasiswa yang memiliki keterampilan emosi yang kurang baik, akan kurang memiliki motivasi untuk belajar (Jonker, 2009). Trisnawati dan Suryaningsum (2003) 
menyatakan bahwa kecerdasan emosional dipengaruhi oleh pengalaman hidup yang dijalani seseorang. Semakin banyak aktifitas atau pengalaman seseorang dalam berorganisasi dan semakin tinggi pengalaman kerja maka kecerdasan emosional mahasiswa akan semakin tinggi. Kecerdasan emosional adalah kemampuan yang dimiliki seseorang dalam mengendalikan perasaan, emosi sehingga mampu memotivasi diri serta mampu mengendalikan dirinya Cook, Bay, Visser, Myburgh dan Njoroge (2011). Durgut, Gerekan dan Pehlivan (2013) menyatakan bahwa pengaruh kecerdasan emosional terhadap pencapaian mata kuliah akuntansi yang dilakukan pada 177 mahasiswa akuntansi di dua universitas negeri yang berbeda di Turki, menemukan bahwa independency, self-fulfillment, social responsibility, flexibility, and problem solving yang merupakan komponen kecerdasan emosional memiliki dampak pada pemahaman mata kuliah akuntansi.

Selain faktor kecerdasan emosional, kecerdasan spiritual juga mempengaruhi tingkat pemahaman akuntansi mahasiswa. Kecerdasan spiritual berkaitan dengan unsur pusat dari bagian diri manusia yang paling dalam menjadi pemersatu seluruh bagian diri manusia lain, yang bertumpu pada bagian dalam diri manusia yang berhubungan dengan kearifan di luar ego atau jiwa sadar, sehingga menjadikan manusia yang benar-benar utuh secara intelektual, emosional dan spiritual. Sehingga kecerdasan spiritual adalah kecerdasan jiwa yang dapat membantu manusia menyembuhkan dan membangun diri manusia secara utuh (Zohar, Danah, \& Marshall, 2002).

Di sisi lain, Ananto (2008) menyatakan bahwa pembelajaran yang hanya berpusat pada kecerdasan intelektual tanpa menyeimbangkan sisi spiritual akan 
Ni Putu Laksmi Gayatri dan I Gst. Putu Wirawati. Pengaruh ...

menghasilkan generasi yang mudah putus asa, depresi, suka tawuran bahkan menggunakan obat-obat terlarang, sehingga banyak mahasiswa yang kurang menyadari tugasnya sebagai seorang mahasiswa yaitu tugas belajar. Kurangnya kecerdasan spiritual dalam diri seorang mahasiswa akan mengakibatkan mahasiswa kurang termotivasi untuk belajar dan sulit untuk berkonsentrasi, sehingga mahasiswa akan sulit untuk memahami suatu mata kuliah. Sementara itu, mereka yang hanya mengejar prestasi berupa nilai atau angka dan mengabaikan nilai spiritual, akan menghalalkan segala cara untuk mendapatkan nilai yang bagus, mereka cenderung untuk bersikap tidak jujur seperti mencontek pada saat ujian. Oleh karena itu, kecerdasan spiritual mampu mendorong mahasiswa mencapai keberhasilan dalam belajarnya karena kecerdasan spritual merupakan dasar untuk mendorong berfungsinya secara efektif kecerdasan intelektual dan kecerdasan emosional (Junifar \& Kurnia, 2015).

Rachmi (2010) menyatakan bahwa belajar di perguruan tinggi merupakan suatu pilihan srategik dalam mencapai tujuan individual seseorang. Semangat, cara belajar, dan sikap mahasiswa terhadap belajar sangat dipengaruhi oleh kesadaran akan adanya tujuan individual dan tujuan lembaga pendidikan yang jelas. Dalam semua aspek ini, pengukuran prestasi akademik merupakan hal-hal yang sangat penting untuk mengetahui tingkat keberhasilan yang dicapai mahasiswa dalam belajar. Dalam proses belajar diperlukan perilaku belajar yang sesuai dengan tujuan pendidikan, dimana dengan perilaku belajar tersebut tujuan pendidikan dapat dicapai secara efektif dan efisien, sehingga prestasi akademik dapat ditingkatkan. 
Perilaku belajar mahasiswa yang terdiri dari kebiasaan mengikuti pelajaran, kebiasaan membaca buku, kunjungan ke perpustakaan, dan kebiasaan menghadapi ujian secara signifikan berpengaruh terhadap pemahaman akuntansi (Lunenburg, 2011). Belajar yang efisien dapat dicapai apabila menggunakan strategi yang tepat, yakni adanya pengaturan waktu yang baik dalam mengikuti perkuliahan, belajar dirumah, berkelompok ataupun untuk mengikuti ujian. Perilaku belajar yang baik dapat terwujud apabila mahasiswa sadar akan tanggung jawab mereka sebagai mahasiswa, sehingga waktu belajar dengan kegiatan di luar belajar dapat mereka bagi dengan baik. Motivasi dan disiplin diri sangat penting dalam hal ini karena motivasi merupakan arah bagi pencapaian yang ingin diperoleh dan disiplin merupakan perasaan taat dan patuh pada nilai-nilai yang diyakini dan melakukan pekerjaan dengan tepat jika dirasa itu adalah sebuah tanggung jawab. Perilaku belajar yang baik dan teratur akan mengasah kemampuan berpikir seseorang dan meningkatkan penguasaan terhadap bidang yang dipelajari. Akuntansi sebagai bidang ilmu yang membutuhkan penalaran, penghafalan, penghitungan tentu membutuhkan latihan untuk menguasainya dengan baik. Oleh sebab itu tingkat pemahaman mahasiswa akuntansi akan lebih baik jika perilaku belajarnya mendukung.

Untuk dapat menghasilkan lulusan yang berkualitas maka perguruan tinggi haurs terus meningkatkan kualitas pada sistem pendidikannya. Kecerdasan yang dimiliki oleh mahasiswa sangat mempengaruhi bagaimana suatu materi yang disajikan dapat dipahami dan diminati, terutama kecerdasan intelektual, kecerdasan emosional, kecerdasan spiritual, dan juga perilaku belajar. Sehingga 
Ni Putu Laksmi Gayatri dan I Gst. Putu Wirawati. Pengaruh ...

penelitian ini penting dilakukan untuk mengetahui tingkat pemahaman akuntansi mahasiswa reguler siang angkatan 2015 Fakultas Ekonomi dan Bisnis Universitas Udayana dan untuk menilai tingkat kecerdasan intelektual, kecerdasan emosional, kecerdasan spiritual, dan perilaku belajar mahasiswa sehingga dapat mengetahui motivasi dan keinginan mahasiswa dalam mengikuti mata kuliah akuntansi.

Kecerdasan memiliki pengertian yang sangat luas. Kecerdasan adalah kemampuan pribadi untuk memahami, melakukan inovasi dan memberikan solusi untuk diri sendiri dalam berbagai situasi. Menurut Dwijayanti (2009) kecerdasan merupakan kemampuan yang dimiliki seseorang untuk melihat suatu masalah lalu menyelesaikannya atau membuat sesuatu yang dapat berguna bagi orang lain. Sehingga dapat diartikan pula bahwa kecerdasan adalah kemampuan untuk menguasai kemampuan tertentu.

Pembawaan ditentukan oleh sifat-sifat dan ciri-ciri yang dibawa sejak lahir. Batas kesanggupan kita yakni dapat tidaknya memecahkan suatu soal, pertama-tama ditentukan oleh pembawaan kita. Orang itu ada yang pintar dan ada yang kurang pintar. Meskipun menerima latihan dan pelajaran yang sama, perbedaanperbedaan itu masih tetap ada.

Kematangan. Tiap organ dalam tubuh manusia mengalami pertumbuhan dan perkembangan. Organ baik fisik maupun psikis dapat dikatakan matang apabila dapat menjalankan fungsinya masing-masing.

Pembentukan ialah segala keadaan di luar diri seseorang yang mempengaruhi perkembangan kecerdasan. Dapat dibedakan pembentukan sengaja 
(seperti yang dilakukan di sekolah) dan pembentukan tidak sengaja (pengaruh alam sekitar).

Minat dan pembawaan yang khas minat mengarahkan perbuatan kepada suatu tujuan dan merupakan dorongan bagi perbuatan itu. Dalam diri manusia terdapat dorongan-dorongan (motif-motif) yang mendorong manusia untuk berinteraksi dengan dunia luar. Motif menggunakan dan menyelidiki dunia luar (manipulate and exploring motivasi). Dari 11 manipulasi dan eksplorasi yang dilakukan dalam dunia luar itu, lama kelamaan timbullah minat terhadap sesuatu. Minat itulah yang mendorong seseorang untuk berbuat lebih giat dan lebih baik.

Kebebasan berarti bahwa manusia dapat memilih metode-metode tertentu dalam memecahkan masalah-masalah. Manusia memiliki kebebasan memilih metode, dan bebas pula memilih masalah sesuai dengan kebutuhannya. Dengan adanya kebebasan ini berarti bahwa minat itu tidak selamanya menjadi syarat dalam perbuatan inteligensi (Dalyono, 2009).

Nuraini (2007) menyatakan bahwa pemahaman akuntansi merupakan suatu kemampuan seseorang untuk mengenal dan mengerti tentang akuntansi. Pemahaman akuntansi merupakan sejauh mana kemampuan untuk memahami akuntansi baik sebagai perangkat pengetahuan (body of knowledge) maupun sebagai proses atau praktik. Berdasarkan definisi diatas dapat disimpulkan bahwa mahasiswa yang dapat dikatakan memahami akuntansi adalah mahasiswa yang menerapkan ilmu akuntansi yang selama ini diperoleh didunia perkuliahan dalam dunia kerja. 
Ni Putu Laksmi Gayatri dan I Gst. Putu Wirawati. Pengaruh ...

Hanum (2011) menyatakan tujuan pemahaman akuntansi adalah memahamkan pengetahuan akuntansi tanpa menimbulkan kekeliruan tentang arti akuntansi, menanamkan sikap positif terhadap pengetahuan akuntansi yang cukup luas lingkupnya. Khususnya untuk mereka yang tidak mengambil jurusan akuntansi, memotivasi agar pengetahuan akuntansi dimanfaatkan dalam praktik bisnis atau organisasi lainnya yang keberhasilannya sebenarnya ditentukan oleh informasi keuangan.

Kecerdasan dalam arti umum adalah suatu kemampuan umum yang membedakan kualitas orang yang satu dengan orang yang lain, kecerdasan intelektual lazim disebut dengan inteligensi. Menurut Zakiah (2013) kecerdasan intelektual adalah kesanggupan untuk menyesuaikan diri secara efektif pada lingkungan yang kompleks dan selalu berubah serta dipengaruhi oleh faktor genetik.

Kecerdasan intelektual merupakan kemampuan menganalisis, logika dan rasio seseorang. Dengan demikian hal ini berkaitan dengan keterampilan bicara, kecerdasan akan ruang, kesadaran akan sesuatu yang tampak, dan penguasaan matematika. Inteligensi mengukur kecepatan kita untuk mempelajari hal-hal baru, memusatkan perhatian pada aneka tugas dan latihan, menyimpan dan mengingat kembali informasi objektif, terlibat dalam proses berfikir, bekerja dengan angka, berpikir abstrak dan analitis, serta memecahkan masalah dan menerapkan pengetahuan yang telah ada sebelumnya.

Kemampuan akademik bawaan, nilai rapor dan prediksi kelulusan pendidikan tinggi tidak memprediksi seberapa baik kinerja seseorang saat orang 
tersebut sudah bekerja atau seberapa tinggi sukses yang akan dicapainya dalam hidup. Kecerdasan emosional menuntut sesorang untuk mengakui, menghargai perasaan diri sendiri dan orang lain serta menanggapinya dengan tepat dan menerapkannya secara efektif dalam kehidupan sehari-hari. Kecerdasan emosional yang membuat perbedaan cara menyelesaikan masalah pada seseorang, dari penyelesaian masalah dalam hidup, pekerjaan dan mengembangkan keterampilan (Modassir, Technologies, \& Singh, 2007).

Kecerdasan intelektual memiliki dimensi yaitu kemampuan memecahkan masalah, intelegensi verbal, dan intelegensi praktis Zakiah (2013). Seorang mahasiswa akuntansi yang memiliki kecerdasan intelektual yang baik maka mampu memahami akuntansi dan dapat membaca dengan penuh pemahaman serta menunjukkan keingintahuan pada akuntansi. Penelitian yang dilakukan oleh Parauba (2014) dan Zakiah (2013) juga menyatakan hal yang sama bahwa kecerdasan intelektual berpengaruh terhadap pemahaman akuntansi. Sedangkan penelitian oleh Dwijayanti (2009) memberikan hasil kecerdasan intelektual tidak memiliki pengaruh terhadap pemahaman akuntansi. Berdasarkan uraian diatas, maka dapat dirumuskan hipotesis sebagai berikut:

$\mathrm{H}_{1}$ : Kecerdasan intelektual berpengaruh positif terhadap pemahaman akuntansi.

Kecerdasan emosional memiliki peran lebih dari 80 persen dalam mencapai kesuksesan hidup, baik dalam kehidupan pribadi maupun kehidupan profesional. Untuk menjadi seorang lulusan akuntansi yang berkualitas, diperlukan waktu yang panjang dan usaha yang keras serta dukungan dari pihak lain yang akan memengaruhi pengalaman hidup lulusan tersebut. Kecerdasan 
Ni Putu Laksmi Gayatri dan I Gst. Putu Wirawati. Pengaruh ...

emosional dapat dilatih, dikembangkan dan ditingkatkan dengan cara mempelajari dan melatih keterampilan serta kemampuan yang menyusun kecerdasan emosional.

Maslahah (2007) menyatakan hasil survei yang di lakukan di Amerika Serikat tentang kecerdasan emosional yang diinginkan oleh pemberi kerja tidak hanya keterampilan teknik saja melainkan dibutuhkan kemampuan dasar untuk belajar dalam pekerjaan yang bersangkutan. Di antaranya adalah kemampuan mendengarkan dan berkomunikasi lisan, adaptasi, kreatifitas, ketahanan mental terhadap kegagalan, kepercayaan diri, motivasi, kerjasama tim dan keinginan memberi kontribusi terhadap perusahaan. Seseorang yang memiliki kecerdasan emosional yang tinggi akan mampu mengendalikan emosinya sehingga dapat menghasilkan optimalisasi pada fungsi kerjanya. Oleh karena itu mahasiswa yang memiliki keterampilan emosi yang baik akan berhasil di dalam kehidupan dan memiliki motivasi untuk terus belajar. Penelitian yang dilakukan Zakiah (2013), Khajehpour (2011) dan Junifar Kurnia (2015) memperoleh hasil bahwa kecerdasan emosional berpengaruh positif terhadap pemahaman akuntansi, namun penelitian yang dilakukan Sahara (2014) menunjukkan bahwa tidak terdapat pengaruh antara kecerdasan emosional dan pemahaman akuntansi. Berdasarkan hasil tersebut, maka dapat dirumuskan hipotesis sebagai berikut:

$\mathrm{H}_{2}$ : Kecerdasan emosional berpengaruh positif terhadap pemahaman akuntansi.

Kecerdasan spiritual adalah landasan yang diperlukan untuk memfungsikan kecerdasan intelektual dan kecerdasan emosional secara efektif. Kecerdasan spiritual yang baik dapat dilihat dari ketulusan, kepercayaan, 
kepemimpinan, pembelajaran, dan keteraturan. Oleh karena itu, mahasiswa yang memiliki kecerdasan spiritual yang tinggi, memiliki ketenangan hati dan selalu yakin bahwa sesuatu yang dilakukan dengan diimbangi dengan berdoa membuat kepercayaan memahami suatu materi yang dipelajari akan menjadi lebih mudah.

Zakiah (2013), Clarken (2010) dan Junifar dan Kurnia (2015) menemukan pengaruh positif kecerdasan spiritual terhadap pemahaman akuntansi. Dengan demikian kecerdasan spiritual berada dibagian diri yang dalam, berhubungan dengan kearifan di luar ego atau pikiran sadar seseorang. Berdasarkan uraian tersebut, maka dapat dirumuskan hipotesis sebagai berikut:

$\mathrm{H}_{3}$ : Kecerdasan spiritual berpengaruh positif terhadap pemahaman akuntansi.

Perilaku belajar adalah suatu aktivitas belajar yang dilakukan suatu individu secara berulang-ulang agar menjadi suatu kebiasaan, sehingga individu tersebut dapat memahami dari hal yang tidak tahu menjadi tahu dan dari hal yang tidak bisa menjadi bisa. Hasil penelitian Junifar Kurnia (2015) bahwa perilaku belajar berpengaruh positif secara signifikan terhadap tingkat pemahaman akuntansi. Hasil serupa ditemukan oleh Artana, Herawati dan Atmadja (2014) bahwa perilaku belajar berpengaruh positif secara signifikan terhadap tingkat pemahaman akuntansi. Namun hasil penelitian Sahara (2014) bahwa perilaku belajar tidak berpengaruh terhadap tingkat pemahaman akuntansi. Hipotesis keempat dalam penelitian ini yaitu sebagai berikut:

$\mathrm{H}_{4}$ : Perilaku belajar berpengaruh positif terhadap pemahaman akuntansi. 


\section{METODE PENELITIAN}

Penelitian ini dilakukan pada mahasiswa jurusan akuntansi angkatan 2015 program S1 reguler siang Fakultas Ekonomi dan Bisnis Universitas Udayana yang beralamat di Jalan P.B. Sudirman, Denpasar.

Populasi dalam penelitian ini adalah mahasiswa jurusan akuntansi reguler siang program S1 angkatan 2015 di Fakultas Ekonomi dan Bisnis Universitas Udayana adalah sebanyak 184 mahasiswa yang aktif. Mahasiswa jurusan akuntansi reguler siang program S1 angkatan 2015 Fakultas Ekonomi dan Bisnis Universitas Udayana dipilih karena kini telah berada di akhir masa perkuliahan sehingga diharapkan telah memiliki gambaran mengenai manfaat maksimal dari proses belajar akuntansi, serta angkatan 2015 adalah angkatan yang selanjutnya akan menempuh dunia kerja. Bila populasi besar, dan peneliti tidak mungkin mempelajari semua yang ada pada populasi, misalnya karena keterbatasan dana, tenaga dan waktu, maka peneliti dapat menggunakan sampel yang diambil dari populasi itu. Apa yang dipelajari dari sampel itu, kesimpulannya akan dapat diberlakukan untuk populasi. Agar jumlah sampel yang diambil dari populasi yang digunakan betul-betul representatif, maka untuk menetapkan jumlah sampel dihitung dengan menggunakan rumus Slovin yang menggunakan nilai kritis sebesar 0,10 .

Rumus: $\frac{\mathrm{N}}{1+\mathrm{N}\left(\mathrm{e}^{2}\right)}=\frac{184}{1+184\left(0.10^{2}\right)}=64,78$

Keterangan:

$\mathrm{N}=$ Jumlah populasi

$\mathrm{e}=$ Batas ketelitian yang digunakan 
Berdasarkan perhitungan di atas maka jumlah sampel dalam penelitian ini adalah sebanyak 64,78 yang kemudian dibulatkan menjadi 65. Dengan demikian jumlah sampel dalam penelitian ini adalah minimal 65 responden.

Perthitungan analisis yang digunakan adalah analisis regresi linier berganda dengan variabel terikatnya adalah pemahaman akuntansi dan variabel bebasnya adalah kecerdasan intelektual, kecerdasan emosional, kecerdasan spiritual, dan perilaku belajar. Model regresi dalam penelitian ini dinyatakan sebagai berikut.

$Y=\alpha+\beta_{1} X_{1}+\beta_{2} X_{2}+\beta_{3} X_{3}+\beta_{4} X_{4}+e$

Keterangan:

Y : Pemahaman Akuntansi

$\alpha \quad$ : Konstanta

$\beta_{1,2,3,4}$ : Koefisien Regresi dari $\mathrm{X}_{1}-\mathrm{X}_{4}$

$\mathrm{X}_{1} \quad$ : Kecerdasan Intelektual

$\mathrm{X}_{2} \quad$ : Kecerdasan Emosional

$\mathrm{X}_{3} \quad$ : Kecerdasan Spiritual

$\mathrm{X}_{4} \quad$ : Perilaku Belajar

e : error

\section{HASIL DAN PEMBAHASAN}

Analisis statistik deskriptif digunakan untuk memberikan informasi mengenai karakteristik variabel penelitian. Statistik deskriptif menjelaskan skala jawaban responden pada setiap variabel independen yang diukur dari nilai minimum, nilai maksimum, nilai tengah (mean) dan standar deviasi. Hasil lengkapnya dapat dilihat pada tabel berikut. 
Tabel 1.

Hasil Statistik Deskriptif

\begin{tabular}{lccccc}
\hline & $\mathrm{N}$ & Minimum & Maximum & Mean & Std. Deviation \\
\hline Kecerdasan Intelektual & 65 & 30 & 50 & 39,52 & 6,167 \\
Kecerdasan Emosional & 65 & 58 & 120 & 93,06 & 14,990 \\
Kecerdasan Spiritual & 65 & 45 & 90 & 70,23 & 11,079 \\
Perilaku Belajar & 65 & 43 & 85 & 66,52 & 12,164 \\
Pemahaman Akuntansi & 65 & 44 & 66 & 55,26 & 6,546 \\
\hline
\end{tabular}

Sumber: Data diolah, 2019

Berdasarkan statistik deskriptif sesuai dengan Tabel 1 diperoleh jumlah pengamatan $(\mathrm{N})$ kecerdasan intlektual sebanyak 65, nilai minimum dari kecerdasan intlektual sebesar 30 sedangkan nilai maksimum sebesar 50. Nilai rata-rata dari kecerdasan intelektual sebesar 39,52 dan standar deviasi sebesar 6,167 .

Berdasarkan statistik deskriptif sesuai dengan Tabel 1 diperoleh jumlah pengamatan $(\mathrm{N})$ kecerdasan emosional sebanyak 65, nilai minimum dari kecerdasan emosional sebesar 58 sedangkan nilai maksimum sebesar 120. Nilai rata-rata dari kecerdasan emosional sebesar 93,06 dan standar deviasi sebesar $14,990$.

Berdasarkan statistik deskriptif sesuai dengan Tabel 1 diperoleh jumlah pengamatan $(\mathrm{N})$ kecerdasan spiritual sebanyak 65, nilai minimum dari kecerdasan spiritual sebesar 45 sedangkan nilai maksimum sebesar 90. Nilai rata-rata dari kecerdasan spiritual sebesar 70,23 dan standar deviasi sebesar 11,079.

Berdasarkan statistik deskriptif sesuai dengan Tabel 1 diperoleh jumlah pengamatan $(\mathrm{N})$ perilaku belajar sebanyak 65 , nilai minimum dari perilaku belajar sebesar 43 sedangkan nilai maksimum sebesar 85 . Nilai rata-rata dari perilaku belajar sebesar 66,52 dan standar deviasi sebesar 12,164. 
Berdasarkan statistik deskriptif sesuai dengan Tabel 1 diperoleh jumlah pengamatan $(\mathrm{N})$ pemahaman akuntansi sebanyak 65, nilai minimum dari pemahaman akuntansi sebesar 44 sedangkan nilai maksimum sebesar 66. Nilai rata-rata dari pemahaman akuntansi sebesar 55,26 dan standar deviasi sebesar 6,546 .

Pengaruh kecerdasan intelektual, kecerdasan emosional, kecerdasan spiritual dan perilaku belajar terhadap pemahaman akuntansi dapat dianalisis menggunakan perhitungan regresi linier berganda di bawah ini:

Tabel 2.

Hasil Analisis Regresi Linier Berganda

\begin{tabular}{|c|c|c|c|c|c|}
\hline \multirow[t]{2}{*}{ Variabel } & \multicolumn{2}{|l|}{$\begin{array}{l}\text { Unstandardized } \\
\text { Coefficients }\end{array}$} & \multirow{2}{*}{$\begin{array}{l}\text { Standardized } \\
\text { Coefficients } \\
\text { Beta }\end{array}$} & \multirow[t]{2}{*}{ t hitung } & \multirow[t]{2}{*}{ Sig. uji t } \\
\hline & $\mathrm{B}$ & $\begin{array}{l}\text { Std. } \\
\text { Error }\end{array}$ & & & \\
\hline (Constant) & 11,938 & 3,816 & & 3,129 & 0,003 \\
\hline $\begin{array}{l}\text { Kecerdasan } \\
\text { Intelektual }\end{array}$ & 0,372 & 0,095 & 0,351 & 3,915 & 0,000 \\
\hline $\begin{array}{l}\text { Kecerdasan } \\
\text { Emosional }\end{array}$ & 0,118 & 0,043 & 0,269 & 2,747 & 0,008 \\
\hline Kecerdasan Spiritual & 0,105 & 0,048 & 0,177 & 2,200 & 0,032 \\
\hline Perilaku Belajar & 0,155 & 0,048 & 0,288 & 3,261 & 0,002 \\
\hline Dependen Variabel & \multicolumn{5}{|c|}{ : Pemahaman Akuntansi } \\
\hline R Square & \multicolumn{5}{|c|}{ : 0,699} \\
\hline $\operatorname{Adjust}\left(\mathrm{R}^{2}\right)$ & \multicolumn{5}{|l|}{$: 0,678$} \\
\hline F Statistik & \multicolumn{5}{|l|}{ : 34,766 } \\
\hline Signifikansi Uji F & \multicolumn{5}{|l|}{$: 0,000$} \\
\hline
\end{tabular}

$$
Y=11,938+0,372 X_{1}+0,118 X_{2}+0,105 X_{3}++0,155 X_{4}
$$

Keterangan :

$$
\begin{array}{ll}
\mathrm{Y} & =\text { Pemahaman Akuntansi } \\
\mathrm{X}_{1} & =\text { Kecerdasan Intelektual } \\
\mathrm{X}_{2} & =\text { Kecerdasan Emosional } \\
\mathrm{X}_{3} & =\text { Kecerdasan Spiritual } \\
\mathrm{X}_{4} & =\text { Perilaku Belajar }
\end{array}
$$

Hasil analisis kelayakan model $\mathrm{F}$ dapat dilihat dari tabel 2 menunjukan bahwa $\mathrm{F}$ hitung sebesar 34,766 dan nilai signifikansi uji $\mathrm{F}$ yaitu sebesar 0,000 
lebih kecil dari 0,05 , hal ini berarti $\mathrm{H}_{0}$ di tolak dan $\mathrm{H}_{\mathrm{a}}$ di terima. Hasil ini memiliki makna bahwa variabel kecerdasan intelektual, kecerdasan emosional, kecerdasan spiritual dan perilaku belajar dapat atau layak digunakan untuk memprediksi variabel pemahaman akuntansi.

Nilai t hitung pada variabel kecerdasan intlektual sebesar 3,915 dan signifikansi sebesar 0,000. Dengan menggunakan batas signifikansi sebesar 0,05 maka nilai signifikansi tersebut lebih kecil dari 5 persen yang berarti $\mathrm{H}_{0}$ di tolak dan $\mathrm{H}_{\mathrm{a}}$ di terima. Hal ini menunjukan bahwa kecerdasan intelektual memiliki pengaruh positif yang signifikan terhadap pemahaman akuntansi. Koefisien regresi variabel kecerdasan intelektual $\left(\mathrm{X}_{1}\right)$ sebesar 0,372 , hal ini berarti bahwa apabila variabel kecerdasan intlektual $\left(\mathrm{X}_{1}\right)$ mengalami peningkatan, maka akan meningkatkan pemahaman akuntansi sebesar 0,372, dengan asumsi variabel bebas konstan.

Nilai t hitung pada variabel kecerdasan emosional sebesar 2,747 dan signifikansi sebesar 0,008. Dengan menggunakan batas signifikansi sebesar 0,05 maka nilai signifikansi tersebut lebih kecil dari 5 persen yang berarti $\mathrm{H}_{0}$ di tolak dan $\mathrm{H}_{\mathrm{a}}$ di terima. Hal ini menunjukan bahwa kecerdasan emosional memiliki pengaruh positif yang signifikan terhadap pemahaman akuntansi. Koefisien regresi variabel kecerdasan emosional $\left(\mathrm{X}_{2}\right)$ sebesar 0,118 , hal ini berarti bahwa apabila variabel kecerdasan emosional $\left(\mathrm{X}_{2}\right)$ mengalami peningkatan, maka akan meningkatkan pemahaman akuntansi sebesar 0,118, dengan asumsi variabel bebas konstan. 
Nilai t hitung pada variabel kecerdasan spiritual sebesar 2,200 dan signifikansi sebesar 0,032. Dengan menggunakan batas signifikansi sebesar 0,05 maka nilai signifikansi tersebut lebih kecil dari 5 persen yang berarti $\mathrm{H}_{0}$ di tolak dan $\mathrm{H}_{\mathrm{a}}$ di terima. Hal ini menunjukan bahwa kecerdasan spiritual memiliki pengaruh positif yang signifikan terhadap pemahaman akuntansi. Koefisien regresi variabel kecerdasan spiritual $\left(\mathrm{X}_{3}\right)$ sebesar 0,105 , hal ini berarti bahwa apabila variabel kecerdasan spiritual $\left(\mathrm{X}_{3}\right)$ mengalami peningkatan, maka akan meningkatkan pemahaman akuntansi sebesar 0,105, dengan asumsi variabel bebas konstan.

Nilai t hitung pada variabel perilaku belajar sebesar 3,261 dan signifikansi sebesar 0,002. Dengan menggunakan batas signifikansi sebesar 0,05 maka nilai signifikansi tersebut lebih kecil dari 5 persen yang berarti $\mathrm{H}_{0}$ di tolak dan $\mathrm{H}_{\mathrm{a}}$ di terima. Hal ini menunjukan bahwa perilaku belajar memiliki pengaruh positif yang signifikan terhadap pemahaman akuntansi. Koefisien regresi variabel perilaku belajar $\left(\mathrm{X}_{4}\right)$ sebesar 0,155 , hal ini berarti bahwa apabila variabel perilaku belajar $\left(\mathrm{X}_{4}\right)$ mengalami peningkatan, maka akan meningkatkan pemahaman akuntansi sebesar 0,155, dengan asumsi variabel bebas konstan.

Koefisien determinasi $\left(\mathrm{R}^{2}\right)$ bertujuan untuk menunjukkan seberapa jauh kemampuan variabel independen dalam menerangkan variasi variabel dependen. Nilai Adjust $\left(\mathrm{R}^{2}\right)$ adalah sebesar sebesar 0,678, hal ini berarti variasi variabel pemahaman akuntansi dapat dijelaskan oleh kecerdasan intelektual, kecerdasan emosional, kecerdasan spiritual dan perilaku belajar sebesar 67,8 persen. 
Sedangkan sisanya sebesar 32,2 persen dipengaruhi oleh variabel-variabel lain diluar model peneilitian.

Hasil analisis menunjukan bahwa kecerdasan intelektual berpengaruh positif dan signifikan terhadap pemahaman akuntansi. Hal ini memiliki makna bahwa semakin tinggi kecerdasan intelektual yang dimiliki maka akan meningkatkan pemahaman akuntansi pada mahasiswa jurusan akuntansi angkatan 2015 Program S1 Reguler Siang Fakultas Ekonomi dan Bisnis Universitas Udayana, begitu juga sebaliknya apabila kecerdasan intelektual yang dimiliki rendah maka akan menurunkan pemahaman akuntansi. Artinya mahasiswa yang memiliki kecerdasan intelektual yang tinggi maka akan lebih mudah dalam memahami akuntansi, ini dikarenakan kecerdasan intelektual merupakan kecerdasan pertama yang dikembangkan yang mampu membuat seorang mahasiswa berfikir secara rasional untuk belajar akuntansi dan memahaminya. Dengan demikian hal ini berkaitan dengan keterampilan bicara, kecerdasan akan ruang, kesadaran akan sesuatu yang tampak, dan penguasaan matematika. Inteligensi mengukur kecepatan kita untuk mempelajari hal-hal baru, memusatkan perhatian pada aneka tugas dan latihan, menyimpan dan mengingat kembali informasi objektif, terlibat dalam proses berfikir, bekerja dengan angka, berpikir abstrak dan analitis, serta memecahkan masalah dan menerapkan pengetahuan yang telah ada sebelumnya.

Hal ini sesuai dengan hasil penelitian yang dilakukan oleh Parauba (2014) dan Zakiah (2013) bahwa kecerdasan intelektual berpengaruh positif dan signifikan terhadap pemahaman akuntansi. 
Hasil analisis menunjukan bahwa kecerdasan emosional berpengaruh positif dan signifikan terhadap pemahaman akuntansi. Hal ini memiliki makna bahwa semakin baik kecerdasan emosional yang dimiliki maka akan meningkatkan pemahaman akuntansi pada mahasiswa jurusan akuntansi angkatan 2015 Program S1 Reguler Siang Fakultas Ekonomi dan Bisnis Universitas Udayana, begitu juga sebaliknya apabila kecerdasan emosional yang dimiliki rendah maka akan menurunkan pemahaman akuntansi mahasiswa. Artinya mahasiswa yang memiliki kecerdasan emosional yang baik maka akan lebih mudah dalam memahami akuntansi, ini di karenakan kecerdasan emosional adalah kecerdasan untuk menggunakan emosi sesuai dengan keinginan, kemampuan untuk mengendalikan emosi sehingga memberikan dampak yang positif. Seseorang yang memiliki kecerdasan emosional yang baik akan memiliki kemampuan untuk mengenal dirinya lebih baik dari segi kemampuan yang dimiliki dan emosi yang dirasakan. Hal ini dikarenakan kemampuan mahasiswa dalam mengelola emosinya dapat membantu dalam mengoptimalkan fungsi kecerdasan intelektualnya. Kecerdasan emosional memungkinkan seseorang untuk memutuskan dalam situasi apa dirinya berada lalu bersikap secara tepat didalamnya.

Hal ini sesuai dengan hasil penelitian yang dilakukan oleh (Zakiah, 2013), Khajehpour (2011) dan Junifar dan Kurnia (2015) bahwa kecerdasan emosional berpengaruh positif dan signifikan terhadap pemahaman akuntansi.

Hasil analisis menunjukan bahwa kecerdasan spiritual berpengaruh positif dan signifikan terhadap pemahaman akuntansi. Hal ini memiliki makna bahwa 
semakin baik kecerdasan spiritual yang dimiliki maka akan meningkatkan pemahaman akuntansi pada mahasiswa jurusan akuntansi angkatan 2015 Program S1 Reguler Siang Fakultas Ekonomi dan Bisnis Universitas Udayana, begitu juga sebaliknya apa bila kecerdasan spiritual yang dimiliki rendah maka akan menurunkan pemahaman akuntansi mahasiswa. Artinya mahasiswa yang memiliki kecerdasan spiritual yang baik maka akan lebih mudah dalam memahami akuntansi, ini di karenakan kecerdasan spiritual adalah sebagai fakultas dimensi non-material kita atau jiwa manusia. Kecerdasan spiritual memungkinkan seseorang untuk menyatukan hal-hal yang bersifat intrapersonal dan interpersonal, serta menjembatani kesenjangan antara diri dan orang lain. Wujud dari kecerdasan spiritual ini adalah sikap moral yang dipandang luhur oleh pelaku, menurut Khavari (2000). Kecerdasan spiritual adalah landasan yang diperlukan untuk memfungsikan kecerdasan intelektual dan kecerdasan emosional secara efektif. Kecerdasan spiritual yang baik dapat dilihat dari ketulusan, kepercayaan, kepemimpinan, pembelajaran, dan keteraturan. Oleh karena itu, mahasiswa yang memiliki kecerdasan spiritual yang tinggi, memiliki ketenangan hati dan selalu yakin bahwa sesuatu yang dilakukan dengan diimbangi dengan berdoa membuat kepercayaan memahami suatu materi yang dipelajari akan menjadi lebih mudah.

Hal ini sesuai dengan hasil penelitian yang dilakukan oleh Zakiah (2013), Clarken (2010) dan Junifar dan Kurnia (2015) bahwa kecerdasan spiritual berpengaruh positif dan signifikan terhadap pemahaman akuntansi.

Hasil analisis menunjukan bahwa perilaku belajar berpengaruh positif dan signifikan terhadap pemahaman akuntansi. Hal ini memiliki makna bahwa 
semakin baik perilaku belajar yang dimiliki maka akan meningkatkan pemahaman akuntansi pada mahasiswa jurusan akuntansi angkatan 2015 Program S1 Reguler Siang Fakultas Ekonomi dan Bisnis Universitas Udayana, begitu juga sebaliknya apa bila perilaku yang dimiliki kurang baik maka akan menurunkan pemahaman akuntansi. Artinya mahasiswa yang memiliki pola perilaku belajar yang baik maka akan lebih mudah dalam memahami akuntansi. Hal ini dikarenakan perilaku belajar yang baik dan teratur akan mengasah kemampuan berfikir seseorang dan meningkatkan penguasaan materi terhadap bidang yang dipelajari. Dalam proses belajar mengajar diperlukan perilaku belajar yang sesuai dengan tujuan pendidikan, perilaku belajar mahasiswa dapat dilihat dari kebiasaan mengikuti pelajaran, kebiasaan membaca buku, kunjungan keperpustakan dan kebiasaan menghadapi ujian.

Hal ini sesuai dengan hasil penelitian yang dilakukan oleh Artana et al. (2014) dan Junifar dan Kurnia (2015) bahwa perilaku belajar berpengaruh positif dan signifikan terhadap pemahaman akuntansi.

Hasil penelitian ini memberikan tambahan informasi mengenai bagaimana kecerdasan intelektual, kecerdasan emosional, kecerdasan spiritual, dan perilaku belajar memengaruhi pemahaman akuntansi. Terdapat bukti empiris yang diperoleh melalui penelitian ini yang menunjukkan bahwa kecerdasan intelektual, kecerdasan emosional, kecerdasan spiritual, dan perilaku belajar berpengaruh pada pemahaman akuntansi. Hal ini menunjukkan bahwa semakin tinggi kecerdasan intelektual, kecerdasan emosional, kecerdasan spiritual, dan perilaku belajar maka semakin meningkat pula pemahaman akuntansi. 
Ni Putu Laksmi Gayatri dan I Gst. Putu Wirawati. Pengaruh ...

Hasil penelitian ini diharapkan dapat memberikan kontribusi positif bagi semua pihak khususnya Fakultas Ekonomi dan Bisnis Universitas Udayana dalam meningkatkan pemahaman akuntansi. Penelitian ini juga menjelaskan bahwa kecerdasan intelektual, kecerdasan emosional, kecerdasan spiritual, dan perilaku belajar yang tinggi akan meningkatkan pemahaman akuntansi sehingga diharapkan akan dapat mengembangkan pemahaman akuntansi di Fakultas Ekonomi dan Bisnis Universitas Udayana.

\section{SIMPULAN}

Kecerdasan intelektual berpengaruh positif dan signfikan terhadap pemahaman akuntansi pada mahasiswa jurusan akuntansi angkatan 2015 Program S1 Reguler Siang Fakultas Ekonomi dan Bisnis Universitas Udayana. Hal ini dapat diartikan bahwa semakin tinggi kecerdasan intelektual yang dimiliki mahasiswa maka akan meningkatkan pemahaman akuntansi mahasiswa.

Kecerdasan emosional berpengaruh positif dan signfikan terhadap pemahaman akuntansi pada pada mahasiswa jurusan akuntansi angkatan 2015 Program S1 Reguler Siang Fakultas Ekonomi dan Bisnis Universitas Udayana. Hal ini menunjukan bahwa dengan memiliki kecerdasan intelektual yang baik maka mahasiswa akan lebih mudah memahami akuntansi.

Kecerdasan spiritual berpengaruh positif dan signfikan terhadap pemahaman akuntansi pada mahasiswa jurusan akuntansi angkatan 2015 Program S1 Reguler Siang Fakultas Ekonomi dan Bisnis Universitas Udayana. Hal ini berarti semakin 
baik kecerdasan spiritual maka semakin meningkat pemahaman akuntansi mahasiswa.

Perilaku belajar berpengaruh positif dan signfikan terhadap pemahaman akuntansi pada pada mahasiswa jurusan akuntansi angkatan 2015 Program S1 Reguler Siang Fakultas Ekonomi dan Bisnis Universitas Udayana. Hal ini menunjukan bahwa semakin baik pola perilaku belajar mahasiswa maka akan meningkatkan pemahaman akuntansi mahasiswa.

Dalam upaya meningkatkan kecerdasan intelektual Mahasiswa Jurusan Akuntansi di Universitas Udayana di harapkan Fakultas Ekonomi dan Bisnis Universitas Udayana dapat dilakukan dengan memberikan tugas-tugas yang lebih menggambarkan praktik nyata dari ilmu akuntansi. Selanjutnya dalam untuk meningkatkan kecerdasan emosional mahasiswa dapa dilakukan dengan memotivasi mahasiswa sehingga munculnya kepedulian agar mahasiswa bisa menjalin hubungan baik dengan orang lain. Dalam upaya meningkatkan kecerdasan spiritual bisa dilakukan dengan sikap belajar untuk menerima, menghadapi dan melampaui rasa sakit. Bagi mahasiswa disarankan untuk melakukan pembelajaran secara berulang-ulang, meningkatkan kebiasaan membaca buku dan memperbaiki kebiasaan dalam mengikuti pelajaran.

Bagi peneliti selanjutnya, agar dapat meneliti dan mengkaji lebih dalam faktor-faktor lain yang tidak diteliti dalam penelitian ini yang dapat mempengaruhi pemahaman akuntansi selain kecerdasan intelektual, kecerdasan emosional, kecerdasan spiritual dan perilaku belajar. Agar nantinya dapat 
mengetahui tindakan apa yang harus dilakukan dalam upaya meningkatkan pemahaman akuntansi.

\section{REFERENSI}

Ananto, H. (2008). Pengaruh Kecerdasan Emosional dan Kecerdasan Spiritual Terhadap Tingkat Pemahaman Akuntansi (Survey pada Perguruan Tinggi di Eks Keresidenan Surakarta). Muhammadiyah Surakarta.

Artana, M. B., Herawati, N. T., \& Atmadja, A. T. (2014). Pengaruh Kecerdasan Intelektual (IQ), Kecerdasan Emosional (EQ), Kecerdasan Spiritual (SQ), dan Perilaku Belajar Terhadap Pemahaman Akuntansi. E-Journal S1 Akuntansi Universitas Pendidikan Ganesha, 2(1). Retrieved from https://ejournal .undiksha.ac.id/index.php/S1ak/article/view/4396

Clarken, R. H. (2010). Considering Moral Intelligence as Part of a Holistic Education. Journal Education, 1(1), 1-9. Retrieved from https://files.eric.ed.gov/fulltext/ ED509643.pdf

Cook, G. L., Bay, D., Visser, B., Myburgh, J. E., \& Njoroge, J. (2011). Emotional Intelligence: The Role of Accounting Education and Work Experience. Issues in Accounting Education, 26(2), 267-286. https://doi.org/10.2308/iace-10001

Daniel, G. (2003). Emotional Intelligence. Jakarta: PT Gramedia Pustaka Utama.

Durgut, M., Gerekan, B., \& Pehlivan, A. (2013). The Impact of Emotional Intelligence on the Achievement of Accounting Subject. International Journal of Business and Social Science, 4(13), 64-71. Retrieved from https://ijbssnet.com/journals/Vol_4_No_13_October_2013/9.pdf

Dwijayanti, A. P. (2009). Pengaruh Kecerdasan Emosional, Kecerdasan Intelektual, Kecerdasan Spiritual, dan Kecerdasan Sosial Terhadap Pemahaman Akuntansi. Universitas Pembangunan Nasional "Veteran."

Jones, G. E. (2008). The link between emotional intelligence and graduate qualities: implications for accounting education. University of Wullongong. Retrieved from https://ro.uow.edu.au/cgi/viewcontent.cgi?referer=https://www.google.c $\mathrm{om} / \&$ httpsredir $=1 \&$ article $=1113 \&$ context $=$ theses

Jonker, C. S. (2009). The Effect Of An Emotional Intelligence Development Programme. Journal of Human Resource Management, 7(1), 157-165. https://doi.org/10.4102/sajhrm.v7i1.183 
Junifar, \& Kurnia. (2015). Pengaruh Kecerdasan Emosional, Kecerdasan Spiritual dan Perilaku Belajar Terhadap Tingkat Pemahaman Akuntansi. Jurnal Ilmu Dan Riset Akuntansi, 4(10), 1-10. Retrieved from http://eprints.ums.ac.id/57328/1/ NASKAH PUBLIKASI.pdf

Khajehpour, M. (2011). Relationship between emotional intelligence, parental involvement and academic performance of high school students. Procedia - Social and Behavioral Sciences, 15, 1081-1086. https://doi.org/10.1016/j.sbspro. 2011.03.242

Khavari, K. A. (2000). Spiritual Intelligence (A Pratictial Guide to Personal Happiness). Canada: White Mountain Publications.

Lunenburg, F. C. (2011). Self-Efficacy in the Workplace: Implications for Motivation and Performance. International Journal of Management, Business and Administration, 14(1), 1-6. Retrieved from http://www.nationalforum.com/ Electronic Journal Volumes/Lunenburg, Fred C. Self-Efficacy in the Workplace IJMBA V14 N1 2011.pdf

Maslahah, R. E. (2007). Pengaruh Kecerdasan Emosional terhadap Tingkat Pemahaman Akuntansi dengan Kepercayaan Diri sebagai Variabel Pemoderasi. Universitas Islam Indonesia.

Mawardi, M. C. (2012). Tingkat Pemahaman Mahasiswa Akuntansi Terhadap Konsep Dasar Akuntansi Di Perguruan Tinggi Negeri Di Kota Malang. Jurnal Ekonomi Dan Bisnis Islam, 8(1), 1-19. https://doi.org/http://dx.doi.org/10.18860/ iq.v0i0.1758

Melandy, R., \& Aziza, N. (2006). Pengaruh Kecerdasan Emosional Terhadap Tingkat Pemahaman Akuntansi, Kepercayaan Diri Sebagai Variabel Pemoderasi. In Simposium Nasional Akuntansi IX: Padang. Padang.

Parauba, I. (2014). Pengaruh Kecerdasan Intelektual, Kecerdasan Emosional, Kecerdasan Spiritual, dan Perilaku Belajar Terhadap Pemahaman Akuntansi Mahasiswa Fakultas Ekonomi Dan Bisnis Universitas Sam Ratulangi Manado. Jurnal Riset Akuntansi, 9(2), 53-67. Retrieved from https://ejournal.unsrat.ac.id/index.php/gc/article/view/5059

Phillips, B. J., \& Phillips, F. (2007). Sink or Skim: Textbook Reading Behaviors of Introductory Accounting Students. Issues in Accounting Education, 22(1), 21-44. https://doi.org/10.2308/iace.2007.22.1.21

Rachmi, F. (2010). Pengaruh Kecerdasan Emosional, Kecerdasan Spiritual, dan Perilaku Belajar Terhadap Tingkat Pemahaman Akuntansi. Universitas 
Diponegoro. $\quad$ Retrieved from http://eprints.undip.ac.id/26538/1/Filia.Rachmi_(C2C606054)(R).pdf

Sahara, M. A. (2014). Pengaruh perilaku belajar, kecerdasan emosional, kecerdasan intelektual, kecerdasan spiritual, dan kecerdasan sosial terhadap pemahaman akuntansi. Jurnal Akuntansi Universitas Maritim Raja Ali Haji, 1(1), 1-23. Retrieved from http://jurnal.umrah.ac.id/wpcontent/uploads/gravity_forms/1-

ec61c9cb232a03a96d0947c6478e525e/2014/05/Masyitah-As-Sahara090462201208-e-journal.pdf

Suwardjono. (2004). Perilaku Belajar di Perguruan Tinggi. Yogyakarta: STIE TKPN.

Trisnawati, E. I., \& Suryaningsum, S. (2003). Pengaruh EQ terhadap Tingkat Pemahaman Akuntansi. In Proceeding Simposium Nasional Akuntansi $V$. Surabaya.

Zakiah, F. (2013). Pengaruh Kecerdasan Intelektual, Kecerdasan Emosional dan Kecerdasan Spiritual Terahap Pemahaman Akuntansi. Universitas Jember. Retrieved

from http://repository.unej.ac.id/bitstream/handle/123456789/ 2054/Farah Zakiah - 090810301086.pdf?sequence=1

Zohar, Danah, \& Marshall. (2002). SQ, Memanfaatkan Kecerdasan Spiritual Dalam Berpikir Integralistik dan Holistik Untuk Memaknai Kehidupan. Bandung: PT. Mizam Media Utama. 